\title{
肢体不自由児の社会的成熟度
}

\author{
橋 本 重 治 - 松原達㦲 - 林邦雄 \\ (東京教育大学) （東京教育大学）（東京教育大学）
}

\section{問 題と目的}

肢体不自由児は、身体的にハンディキャップがあっ て、社会と接触する機会が著しく制限され、社会や隣人 に対する自己の態度が未熟であり、未分化であるため に、普通児に比較して社会的成熟度は遅れているといわ れている(6)15)。特に、脳性まひ児（C P览）の場合は、 作栄能力、運動能力、集団への参加、自発性などの遅れ が月だち、平均 $\mathrm{S} Q$ (社会成熟度指数) は57であっで）

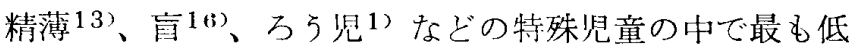
い。

しかし、ひとくらに肢体不自由児といっても、その種 類や起因疾患なぞ横の広がり、またその程度、さらに原 因之現象の区別など非常に複雑であって、社会的生活能 才の程度も種々異なっている。筆者らは、先にC P 児全 休の社会的成熟度汇ついての研究を報告したが8、ここ では、C P 児と Polio（ポリオ）児についてつぎのよ5 な三つの面から研究することを目的とした。

1） C P児の中でも身体障害の程度によって社会的生 活能少の発羍はどのよ5に異なるかを研究すること。

2） C P 児と Polio 児の社会的生活能力の発達につい て此較研究すること。

3）肢体不白由児の社会的成熟度の倜人善について研 笕すること。

\section{方法}

1. 調查内容と評定者

奏際の調查は、社会成熟度診断検查17)を使用したが、 その内容は、(1)作業能力 (2)運動（移動）能力 (3)意志 交換能力 (4)集団一の参加能力 (5)自発性 (6)自己統制 (7)基本的習慣（@清潔 (b排泄 (C)着衣 (d)睡眠 (e)食 护）の 7 領域 180 項目からできている。各項目は、子ぞ もの世話をよくし、子どもを最もよく知っている保護者 または保母に、各行動項目がぞの程度実行されているか を評定してもらった。その評定は、日常生活での諸能力 を「できる」「できるだろう」「できない」「できない
だろう」の4段階にわけて行ない、前 2 者の評定をいず 孔も 1 閣 1 点、後 2 者の評定をいずれも 1 問 0 点とし た。

2. 調查対象

(1) 調 查 校

わが国の人口分布を考慮し、全国の肢体不白由盖護学 校からつぎの10校を選んだ。

(1) 北海道真駒内養護学校

(2) 岩手県立養護学校

(3) 東京教育大学付属桐ヶ丘養護学校

(4) 東京都立江戸川養護学校

(5) 新潟県立養護学校

(6) 愛知県立名古屋養護学校

(7) 神戸市立友生養護学校

(8) 大阪市立光陽養護学校

(9) 広島県立盖護学校

(10) 福島県立養護学校

（2） C P览の障害部位别分類

各担任教師が医師の診断結果に基づいて報告してきた 個人調查票にそってC P览を障㕩部位别に分類した。そ

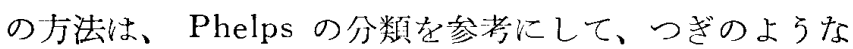
$\mathrm{P}, \mathrm{Q}, \mathrm{H}, \mathrm{T}$, の4群にわけた。

$\mathrm{P}$ …両下肢屯ひ（パラプレギア、ディプレギアに対応）

$Q \cdots$ 雨上肢両下肢末ひ（四肢委ひ詨応）

$\mathrm{H} \cdots$ 体の片側まひ（牌ひに対応）

$\mathrm{T} \cdots$ 片側の上肢と”下肢末ひ（三股末ひ江対灾）

(3) Polio 巟の診断

Polio 览の診断は、前述と同㥞、各校の医師の榕断結 果に基ついて备担任教的が報告してきたものによって部 断した。

(4) 調查対象

上記各校の小 $1 \sim 6$ 年までの全員 851 名に実施し、そ の中から調査記入の完全なC P 児 588 名と Polio 巟98名 を選出し、統計処理を行なった。C P 睍の年令別、性 別、病型别、知能別の人数は Table 1 のようであり、 Polio 児の年令別、性別、学年斺、知能別人数は Table 


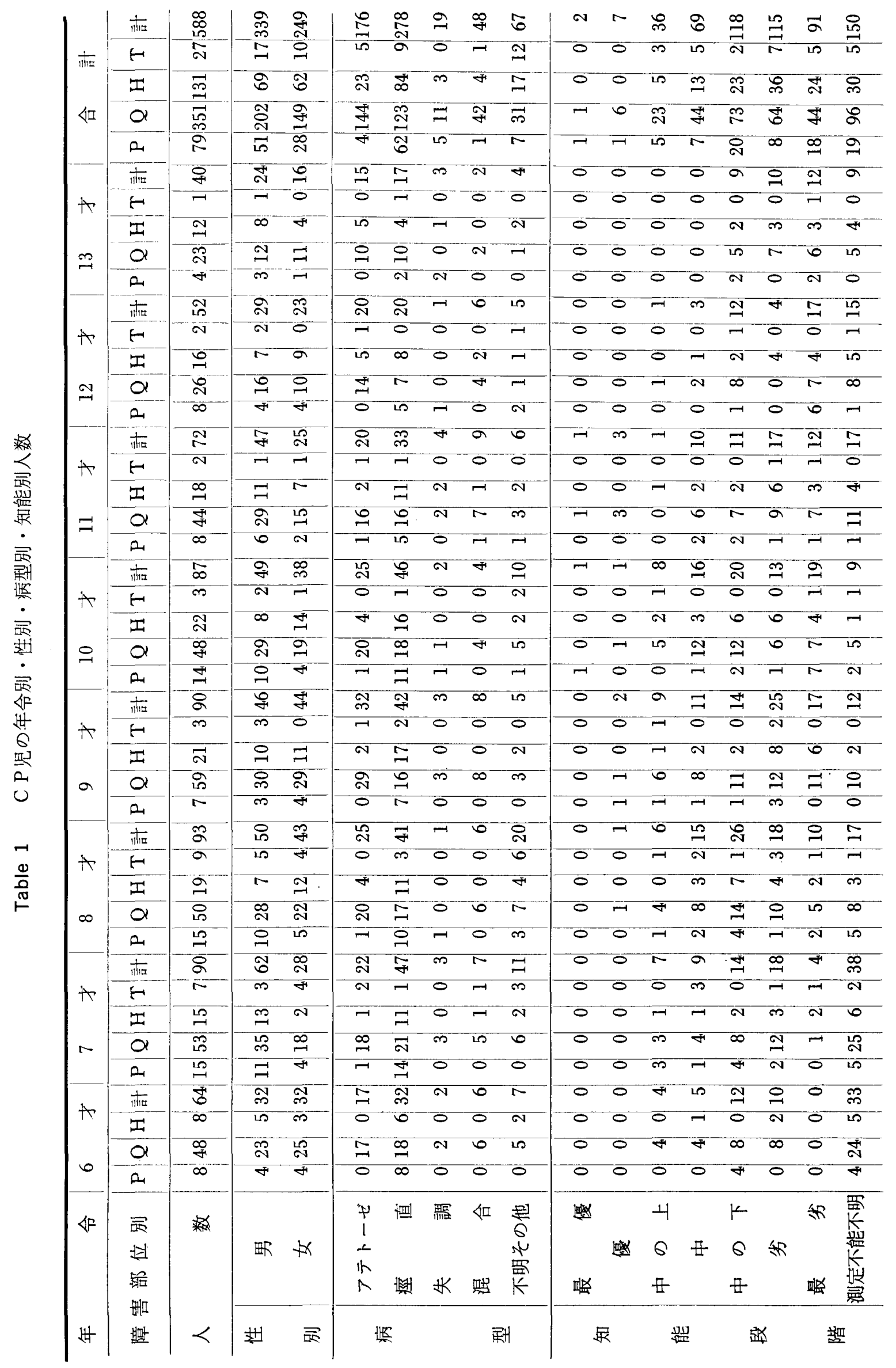


Table 2 Polio 児の年令別・性别・学年別・知能別人数

\begin{tabular}{|c|c|c|c|c|c|c|c|c|c|c|}
\hline 年 & 令 & $6 才$ & $7 才$ & 8 才 & $9 才$ & $10 才$ & $11 才$ & $12 才$ & $13 才$ & 計 \\
\hline 人 & 数 & 10 & 14 & 17 & 10 & 23 & 19 & 4 & 1 & 98 \\
\hline 性 & 男 & 3 & 6 & 6 & 7 & 15 & 12 & 1 & 1 & 51 \\
\hline 別 & 女 & 7 & 8 & 11 & 3 & 8 & 7 & 3 & 0 & 47 \\
\hline & 小 1 & 10 & 5 & 1 & & & & & & 16 \\
\hline 学 & 小 2 & & 9 & 2 & & & & & & 11 \\
\hline & 小 3 & & & 14 & 3 & & & & & 17 \\
\hline & 小 4 & & & & 7 & 5 & & & & 12 \\
\hline 年 & 小 5 & & & & & 18 & 9 & & & 27 \\
\hline & 小 6 & & & & & & 10 & 4 & 1 & 15 \\
\hline & 最 優 & & & & & & & & & 0 \\
\hline 知 & 優 & & 1 & 4 & 1 & 2 & 2 & 1 & & 11 \\
\hline & 中の上 & 5 & 3 & 4 & 4 & 5 & 6 & & & 27 \\
\hline 能 & 中 & 4 & 6 & 3 & 2 & 6 & 9 & 1 & & 31 \\
\hline 段 & 中の下 & 1 & 2 & 1 & 1 & 3 & & 1 & 1 & 10 \\
\hline & 劣 & & 1 & 1 & & & & & & 2 \\
\hline 階 & 最 少 & & & & & 1 & 1 & & & 2 \\
\hline & 不 明 & & 1 & 4 & 2 & 6 & 1 & 1 & & 15 \\
\hline
\end{tabular}

2 のようである。

性別では、C P巟の場合男子 $58 \%$ に対し女子 $42 \%$ の割 合でやや男子が多いが、Polio 児は汪とんど差がない。 病型別では、痤直型が47\%、アテトーゼ型が $30 \%$ で失調 型・混合型は僅少である。学年別では、C P児の場合、か なり過年児がいるが、Polio 児は僅少である。知能分布 は、C P巟は一般に I Qは低いが、14)本研究でも低く、 さらに Polio 児は中以上のものが約 7 割で、普通児と注 とんど変わらない。

(5) 調查期間

昭和 41 年 5 月 1 日 6 月 15 日

(6) 各領域別の得点算出法

7 領域 180 の各項目について、1 点または 0 点に評定 し、各領域ごとに得点を合計した。各領域ごとの合計得 点は、20点または10点（基本的習慣の場合）のいずれか である。

（7）普通児の比較資料

1964年に松原が 4 〜才をでの普通児 3,000 人を対象 に調査研究した資料を ${ }^{11}$ 。普通罗の比較資料とした。

\section{結果とその考察}

\section{C P 児の障害部位別社会的成熟度}

C P 児を障害部位別に分類した $\mathrm{P}, \mathrm{Q}, \mathrm{H}, \mathrm{T}$ ，について、 6〜13才まで発達的に社会的成熟度の各領域の得点を比
較検討した。その結果は、Table 3，4のよ5である。な 执この表には、調查対象数が 5 人以下の昜合は、比較資 料としての信頼性が低いために、記載しなかった。

な特、C P览の障害部位別に、4つに分類したが、こ こでは、調査対象数が多くて、しかもどちらかといえば 障害の重いものを多く含んでいる $Q$ (両上肢两下肢まひ) と、どちらかとい章害の軽いものを多く含んでいる $\mathrm{P}$ (両下肢玉ひ)の二群について比較検討した。その結果 は、Fig. 1〜13のよ5である。結果は、年令により領域 によって多少の違いはあるが $\mathrm{Q}$ 群は $\mathrm{P}$ 群よりも発達が遅 れている。特に、作業能力 (Fig. 1)、清潔・着衣・食 事などの基本的習慣（Fig. 7，9，11）の発達には、差が 大きい。基本的習慣全体（Fig. 12）の発達を比較する と、6〜9才执よび11才では、1\%の水準で有意差があ つた。社会的成熟度総得点（Fig. 13）においても全く同 樣の年令で有意差があった。10才と12才ではあまり差が ないのは、 sample に偏りがあったよ5にも思われる （特に両下肢をひでも重いものが多かった）が、その点 は、他の資料によってさらに検討しないと確実なことは いえない。

普通児ができるよ5な本調查項目に含まれるところの 運動能力は、全体として雨群とも低いが、Q群は $\mathrm{P}$ 群よ りさらに低い傾向がある。しかし、その差は小さい。意 志交換能力、集団への参加能力、自己統制などは、両群 にあまり差がない。排泄、睡眠などの生活猊慣は、両群 とも6才で90\%以上完成しているので、以後の年令に拉 いても発達差はあまりない。

以上比較してみると、日常の生活動作に直接影響を与 えるような諸動作たとえば作業能力、清潔、着农、食事 などの諸能力においては、同じC P巟でも障害の重いる のが、その発達が遅れていることが目立つ。反面、こと ばや知的意志的な能力たと艺ば意志交換能力、集四への 参加能力、自発性、自己統制などの諸能すに扣いては、 これらの傾向はあまりみられなかった。全体の社会的成 熟度得点に括いては、やはり、Q群が $\mathrm{P}$ 群よりも発達が 遅れていた。な拉、Q群の平均 $\mathrm{S} Q$ は 54 であり、P群の 平均 $\mathrm{S} Q$ Q65であった。

2. C P 児とPolio 児との比較

C P 児とPolio 児との社会的成熟度について比較し た。C P 児は 6 才〜12才をでの 548 名とPolio 児の同年 の98名とを年令別に各領域別に比較検討した。Table 5 拈よびFig. 1〜13にその結果を示した。

これらをみてもわかるように、社会生活能力执よび基 本的習慣のどの領域を比較しても Polio 児はC P览より 
| 1 | 1ㅇำ

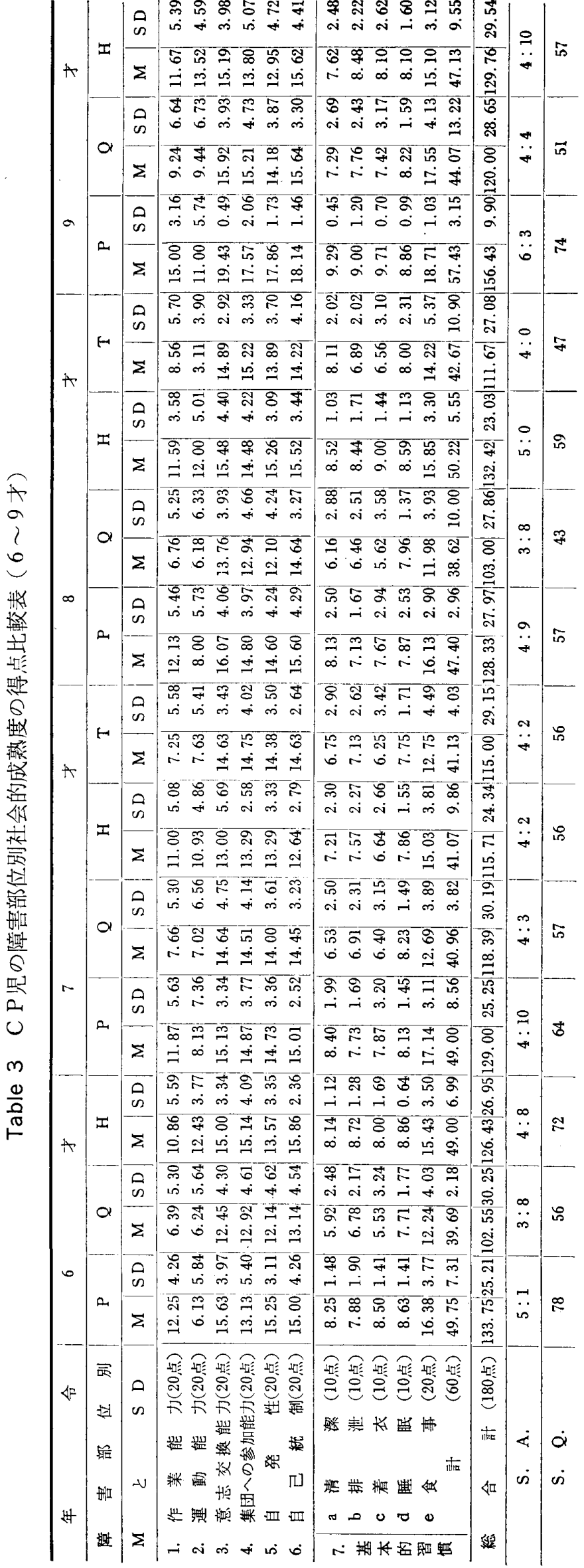

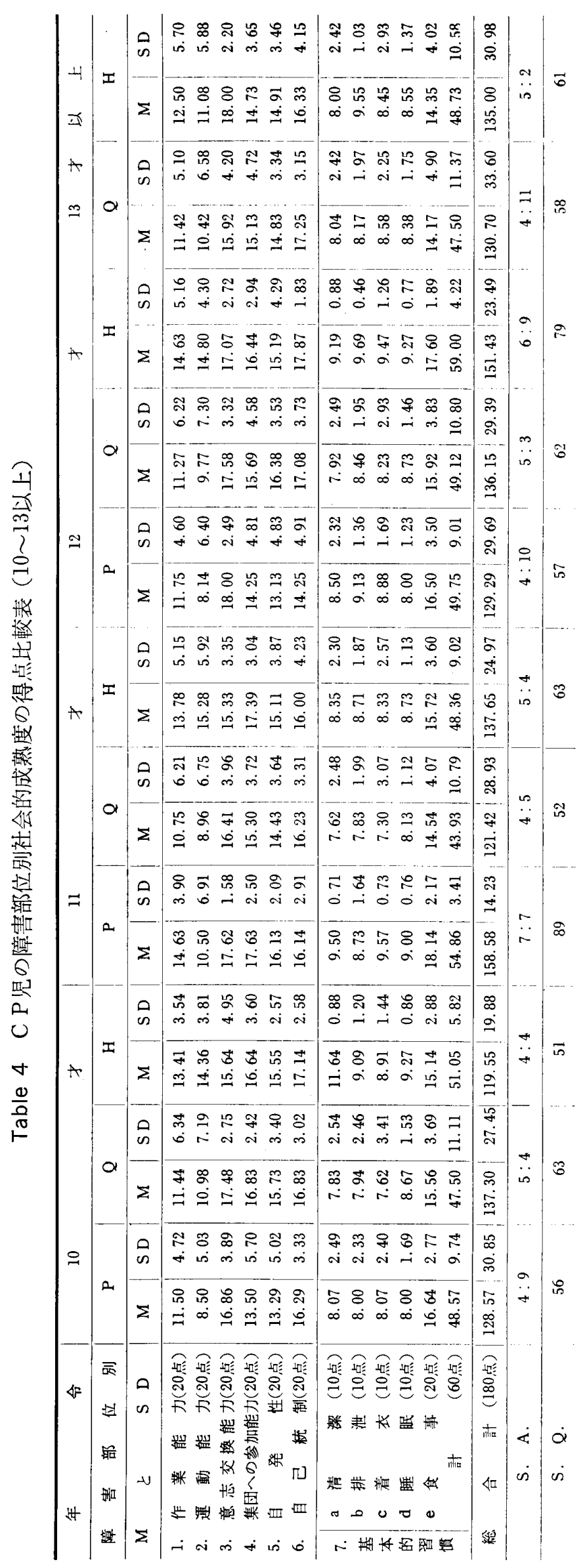



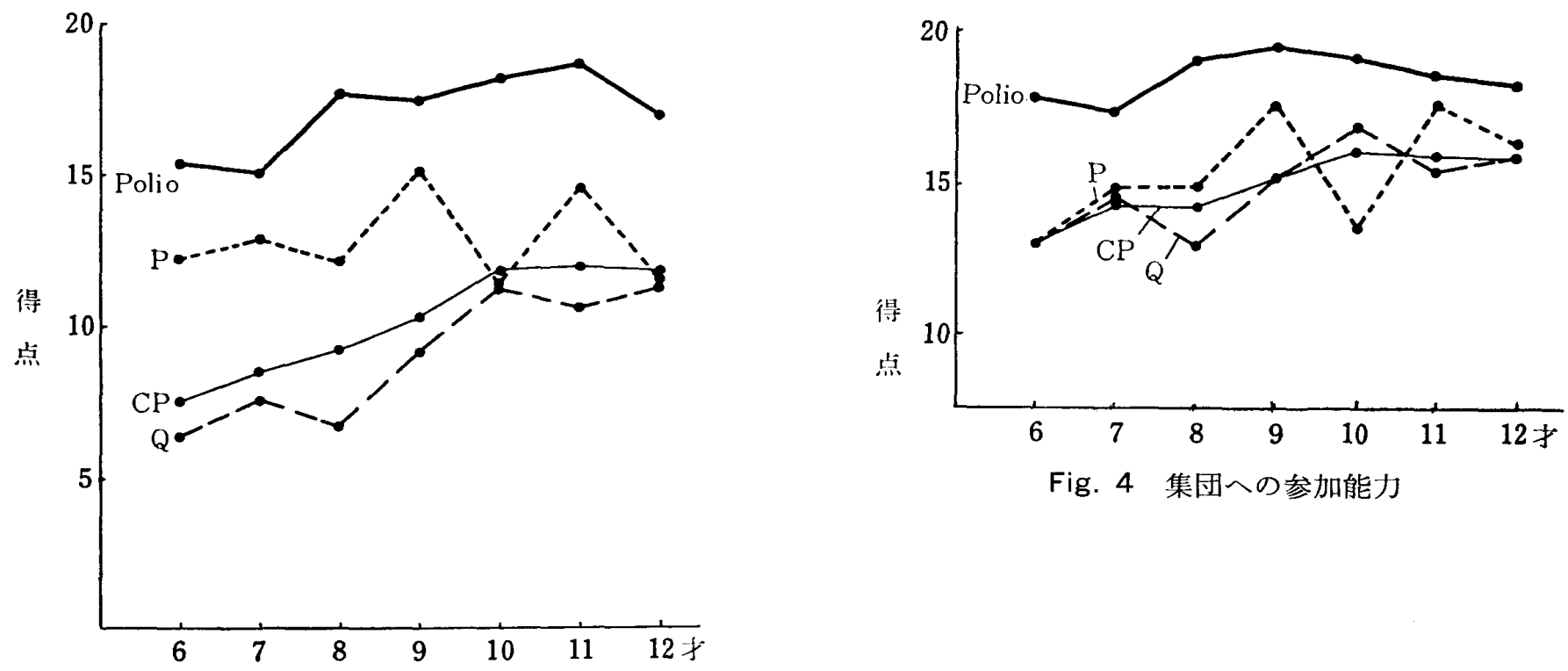

Fig. 4 集団人の参加能力

Fig. 1 作 業 能力
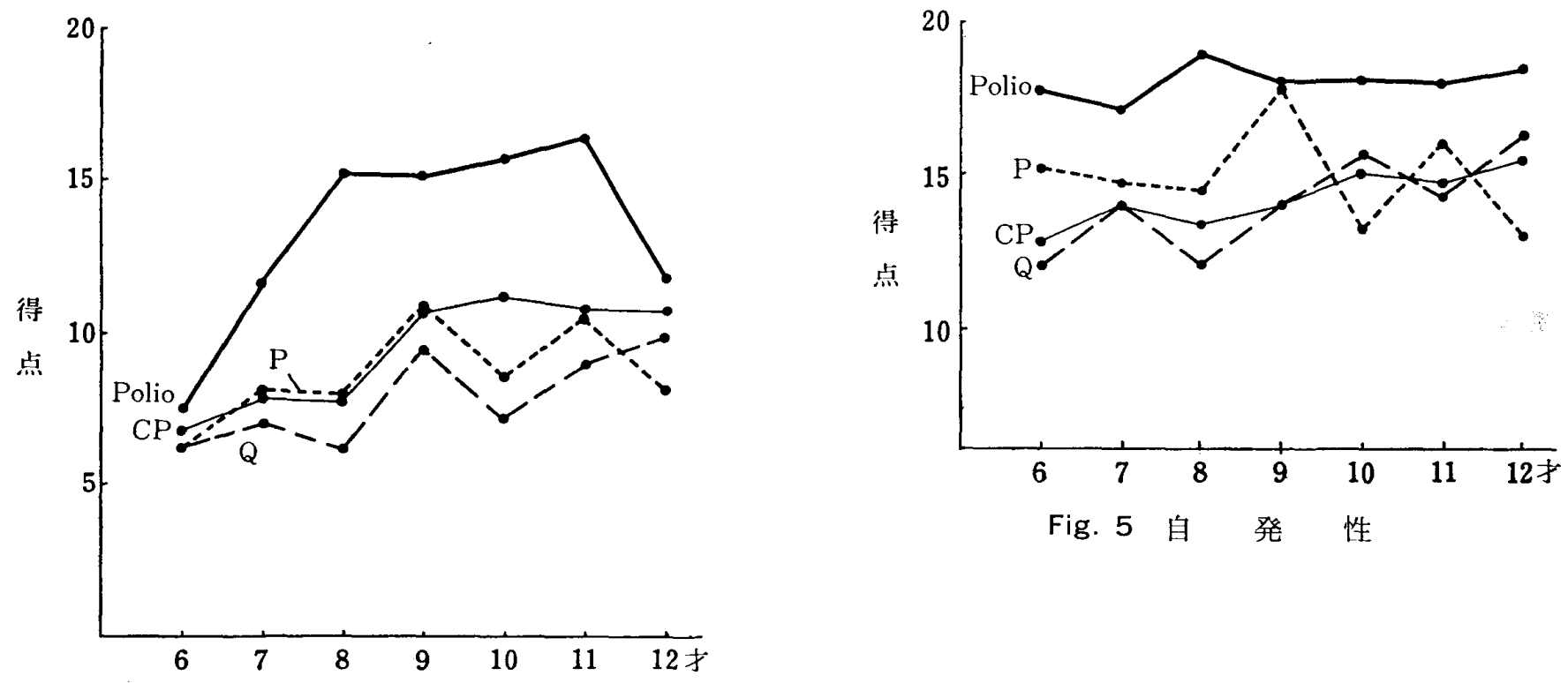

Fig. 5 自 発 性

Fig. 2 運 動 能力
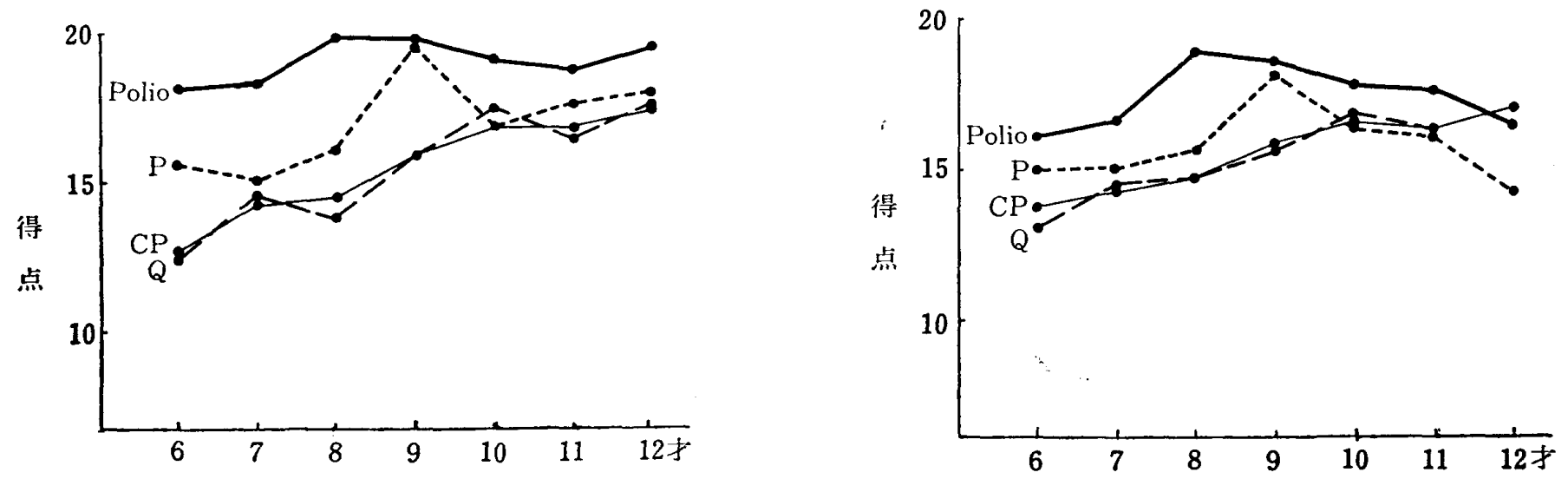

Fig. 3 意志交換能力 


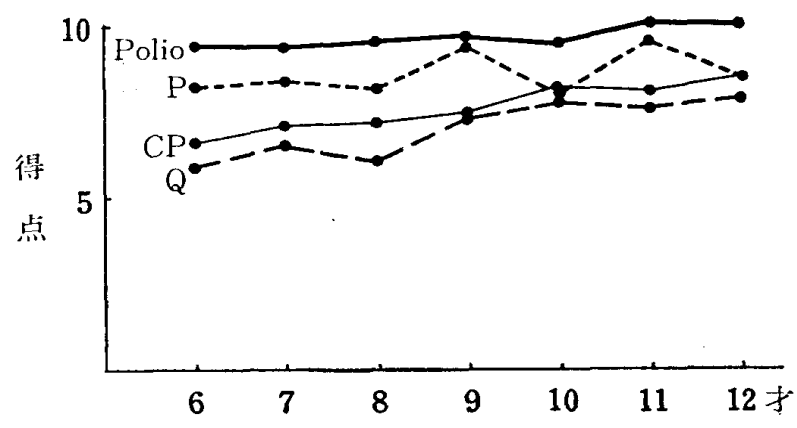

Fig. 7 清

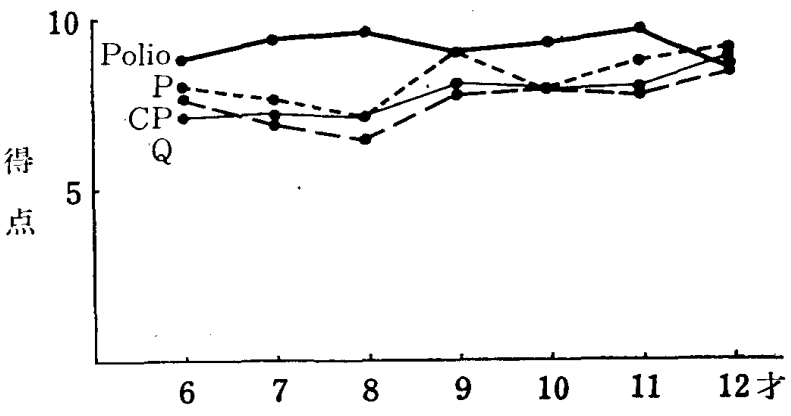

Fgi. 8 排

泄

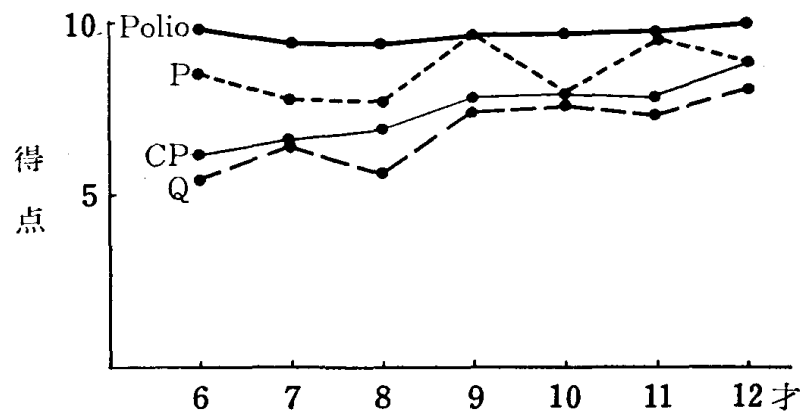

Fig. 9 着

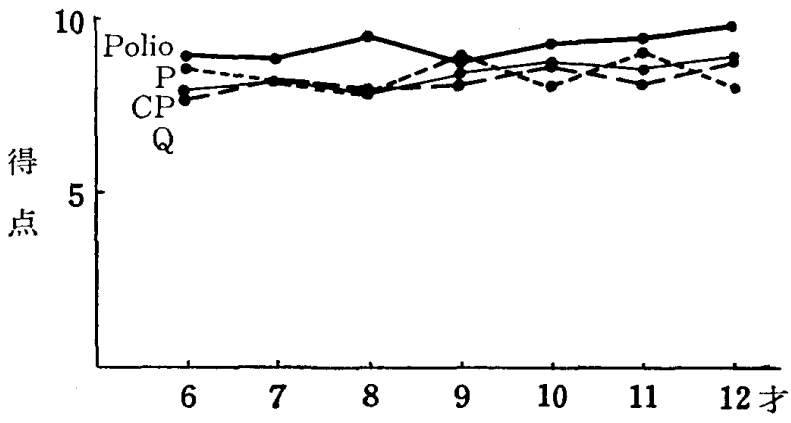

Fig. 10 睡
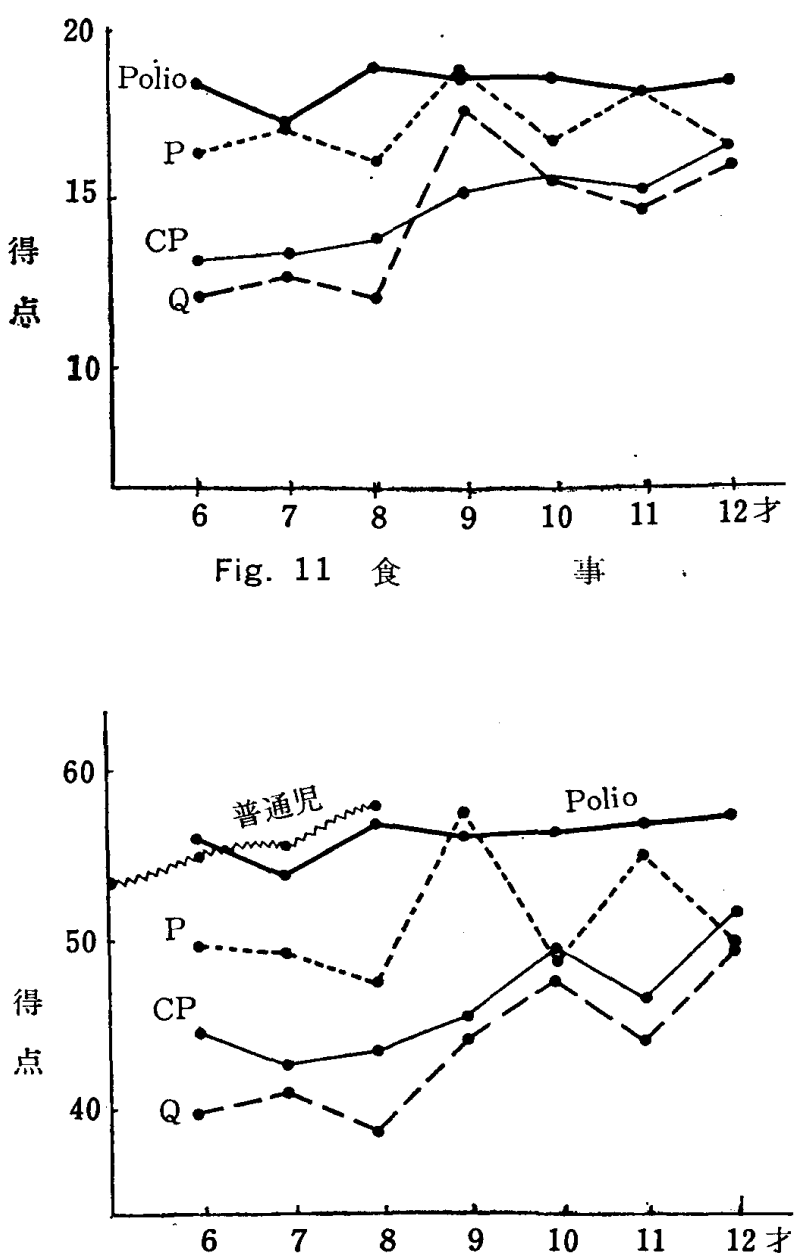

Fig. 12 基本的習慣全体

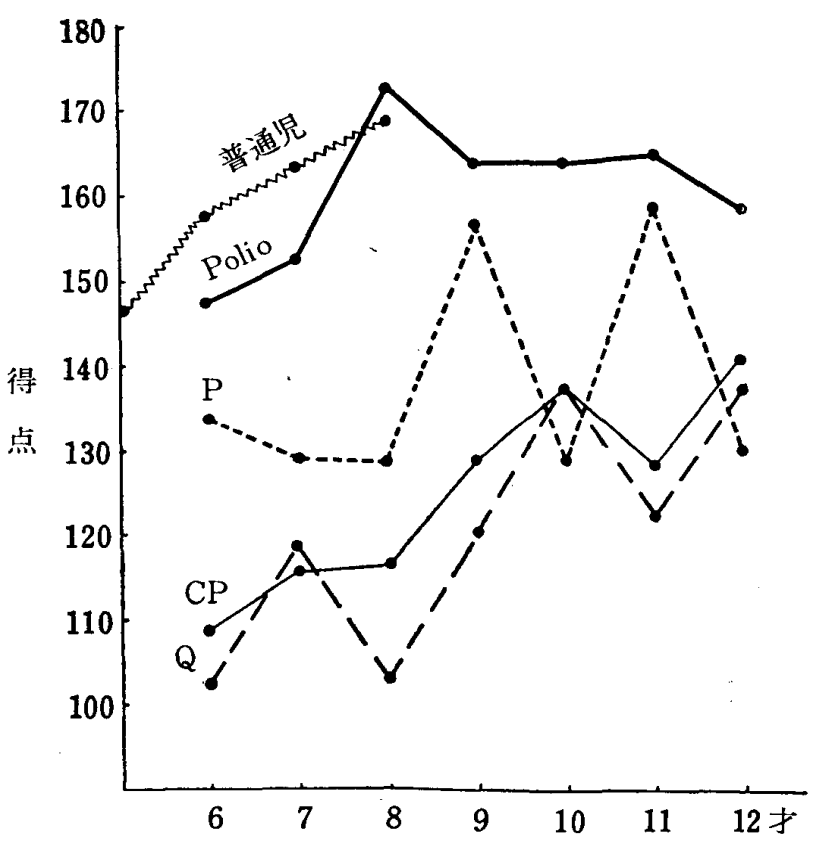

Fig. 13 社会成熟度総得点 


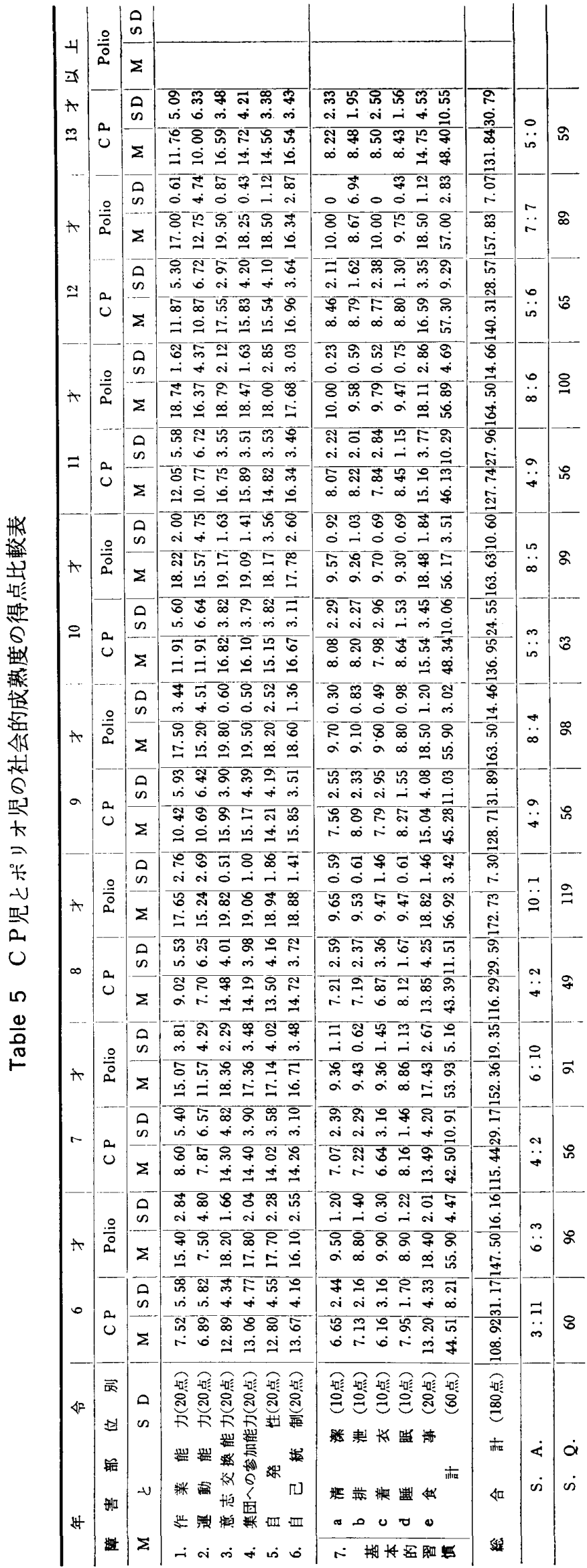

も優れている。このことは、一部の年令を除いて、（運 動能力の 6 才、12才、自己統制の 12 才、排泄の 12 才、着 衣の12才、睡眠の $6 〜 7$ 才、 9 １2才では有意差なし）共 通にい方る。前回の C P 児と普通児の社会的成熟度の研 究に执いては、C P 児は普通児に比較してかなり遅れて いたが、その崌れの程度と泳㳯類似した傾向を示してい る。試みに普通児の $5 \sim 8$ 才までの基本的習慣全体の発 達と社会的成熟度全体の発達とについて Polio 児と比較 すると（Fig. 12，13）両群とも、同じような発澾傾向を 示している。Polio 児は、他の領域に执いても大体普通 児と同じような挠達傾向を示している。C P 児の平均 $\mathrm{S}$ Qは57であり、Polio 児の平均 S Q 101 であり、肢体 不自由児全体の平均 S Qは64であった。

Polio 児は、C P 児と違って、ポリオ・ビールスによ って脊髄が侵されているが、知能的には正常児とほとん ぞ変らないので、社会生活に括ける知的障害は少ない。 性格的にもやや外向的であって、まひの部位と程度によ って違らが、杖とか補装具などの補助手段によって、移 動能力に制約をうけるとしても、かなり常人に近い生活 を送ることができる。また、Polio 児の中には、大学に 進学したり、社会生活に適応して自立しているものもい て、社会性の未成熟でないことは容易に推察できる。

一方 C P 児は、大脳の非進行性病変に基づく運動和上 び肢位の異常のある肢体不自由であって、その症状や精 神的特質には違いはあるが、運動発達に遅れが目立ち、 しばしば知能も低く、性格的発達のひずみ、言語障害、 視覚・聴覚障害などの随伴障害があって、Polio 児に比 較すると、社会的生活能力の遅れも当然予想される。事 実、社会生活に和沙自立も困難であって、将来のリ八 ビリテーション計画にも問題が多い。

な打、C P児とPolio 児について、社会生活経験や見 聞の広さと深さを考えてみても、Polio 坚は、知的に障 害がなく、運動発達も C P 児よりよいため、行動の範囲 が広く、接触する人の数や機会も多い。伊藤徹らの肢体 不自由児の経験的背景の実態調查 ${ }^{10}$ に抢いてもPolio 児よりも C P 児において、経験不足がいっそう顕著であ ることを報告している。

次に、各問題項目を比較してみて、Polio 児と C P 児 との発達にどの程度の美があるかを、それぞれの可能年 令をむとに比較してみた（Table 6)。この場合の可能年 令の算出方法は、牛島義友の基準 19) を参考に各問題項 目の通過率を算出し、通過率70\%前後を、その項目の実 行がだいたい「できる」「できない」のわかれる年令と 考えて、それを可能年令とした。 
Table 6 Polio 児と C P览の可能年令差

(1) 作業能力 (occupation)

\begin{tabular}{|c|c|c|c|c|c|c|c|}
\hline No. & 項 & \begin{tabular}{|l|} 
Polio \\
可能年令 \\
\end{tabular} & 同年令 & 1 年差 & 2 年差 & 3 年差 & $\begin{array}{l}\text { 4年差 } \\
\text { 上 上 }\end{array}$ \\
\hline 1 & 軽い荷物（カバン）なら両手にもって運べる & 7 才 & & & $\bigcirc$ & & \\
\hline 2 & 1 枚ずつ本の紙をめくる & $6 才$ & 0 & & & & \\
\hline 3 & 水のはいったコップをこぼさないで運べる & $7 \Varangle$ & & & & & \\
\hline 4 & はさみで三角や円などの簡単なものがきりとれる & 6 才 & & & & & 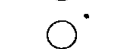 \\
\hline 5 & かんたんなぞうきんがけができる & 6 才 & $\bigcirc$ & & & & \\
\hline 6 & ほうきが使える & 7 才 & & & & & J \\
\hline 7 & 折紙ができる & $6 才$ & & & & & 0 \\
\hline 8 & ひもをむすんだり、はどいたりできる & 6 才 & & & & & 0 \\
\hline 9 & はりえやはり紙のとき、のりつけがきちんとできる & 6 才 & & & & & 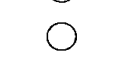 \\
\hline 10 & ぞうきんや手拭いがしぼれる & 6 才 & & & & & $\bigcirc$ \\
\hline 11 & 子もりや和使いができる & $8 才$ & & & & & $\gamma$ \\
\hline 12 & 金づちがつかえる & 6 才 & & & & & 0 \\
\hline 13 & ナイフやほうちょらが使える & 6 才 & & & & & 0 \\
\hline 14 & ときどき雨戸をあけたり、そうじをしたりする & 8 才 & & & & & $\bigcirc$ \\
\hline 15 & 靴の手入れができる & 6 才 & & & & & $\bigcirc$ \\
\hline 16 & マッチで火がつけられる & 6 才 & & & & & $\mathrm{O}$ \\
\hline 17 & 鉛筆をけずって使う & 6 才 & & & & & 0 \\
\hline 18 & お湯をわかすことができる & $6 \nsucc$ & & & & & $\bigcirc$ \\
\hline 19 & 草花の栽培や小鳥や家畜の飼育ができる & 6 才 & & & & & 0 \\
\hline 20 & 自転車にひとりでのれる & 8 才 & & & & & $\bigcirc$ \\
\hline
\end{tabular}

（2）運動（移動）能力 (Locomotion)

\begin{tabular}{|c|c|c|c|c|c|c|c|}
\hline No. & 項 & \begin{tabular}{|l} 
Polio \\
可能年令
\end{tabular} & 同年令 & 1 年差 & 2 年差 & 3 年差 & $\begin{array}{l}4 \text { 年差 } \\
\text { 以 }\end{array}$ \\
\hline 1 & ひとりで階段を1つずつのぼれる & $8 才$ & & O & \multirow[b]{5}{*}{$\bigcirc$} & \multirow{5}{*}{0} & \multirow{5}{*}{$\bigcirc$} \\
\hline 2 & 走ることができる & $10 才$ & & & & & \\
\hline 3 & 階段を 1 足ずつおうることができる & 8 才 & & 0 & & & \\
\hline 4 & 庭を歩さまわる & 6 才 & & & & & \\
\hline 5 & すべり台を危険なくすべる & $8 才$ & & & & & \\
\hline 6 & いすを使って、棚から物をとることができる & $8 才$ & & & & & \multirow{5}{*}{$\begin{array}{l}0 \\
0 \\
0 \\
0 \\
0\end{array}$} \\
\hline 7 & 両足をそろえてとぶ & $9 才$ & & & & & \\
\hline 8 & $30 \mathrm{~cm}$ のゆなあたいでとべる & $7 才$ & & & & & \\
\hline 9 & ひとりで幼稚園や学校にいける & 7 才 & & & & & \\
\hline 10 & ひとりで技友だちの家へいける & 7 才 & & & & & \\
\hline 11 & ポストにハガキを入れることができる & 6 才 & & & & $\bigcirc$ & \multirow{5}{*}{$\bigcirc$} \\
\hline 12 & ぶらんこに立ってひとりでこげる & 8 才 & & & & & \\
\hline 13 & $\begin{array}{l}\text { はじめてのところでも近いところなら、遊びにひとりでい } \\
\text { ける }\end{array}$ & 7 才 & & & & & \\
\hline 14 & 車のよくとおる道をひとりで安全に歩ける & 8 才 & & & & & \\
\hline 15 & 交美点を信号ど就りにわたる & 7 才 & & & & & \\
\hline
\end{tabular}




\begin{tabular}{l|l}
16 & 自分の町や村を自由に步ける \\
17 & なわとびができる \\
18 & 夜でも簡単なお使いができる \\
19 & 入場券や乗車券がひとりで買える \\
20 & ひとりで電車やバスにのれる
\end{tabular}

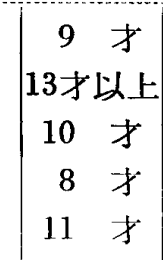

（3）意志交換能力 (Communication)

\begin{tabular}{|c|c|c|c|c|c|c|c|}
\hline No. & 項 & \begin{tabular}{|l|} 
Polio 9 \\
可丁能年令
\end{tabular} & 同年令 & 1 年美 & 2 年差 & 3 年差 & $\begin{array}{l}4 \text { 年差 } \\
\text { 以 } 1\end{array}$ \\
\hline 1 & 自分の名まえがいえる & 6 才 & O & & & & \\
\hline 2 & ほしいものをねだる & 6 才 & $\bigcirc$ & & & & \\
\hline 3 & 自分でみたり聞いたりしたことを話す & $6 才$ & $\bigcirc$ & & & & \\
\hline 4 & 名まえをよばれたとき「はい」と返事する & 6 才 & O & & & & \\
\hline 5 & 先生や友だちの名まえを正しくよべる & $6 才$ & O & & & & \\
\hline 6 & いろいろなことを質問する & 6 才 & O & & & & \\
\hline 7 & 「おはよう」「さようなら」が正しくいえる & 6 才 & $\bigcirc$ & & & & \\
\hline 8 & 簡単なことづけを間違いなくできる & $6 才$ & O & & & & \\
\hline 9 & 幼児語（わんわん、ちんぶん、おかちなど）を使わない & $6 才$ & $\bigcirc$ & & & & \\
\hline 10 & 簡単な買物なら自分でできる & 6 才 & & & & & O \\
\hline 11 & 「ありがとら」が必要なときに、いつもはっきりれえる & 6 才 & $\bigcirc$ & & & & \\
\hline 12 & 自分の家から学校 (幼稚園) までの道順がだいたいいえる & $7 \Varangle$ & & & & & $\bigcirc$ \\
\hline 13 & 自分の住所が正しくいえる & $6 才$ & & 0 & & & \\
\hline 14 & ひとが話すときは聞いていて、すんでから話す & 6 才 & & & & O & \\
\hline 15 & 自分の名まえを正しく書くことができる & 6 才 & & O & & & \\
\hline 16 & 1 時間単位でだいたいの時刻がわかる（3 時とか 5 時を） & & & $\mathrm{O}$ & & & \\
\hline 17 & 絵本の文字をすらすらよむ & 6 才 & & & & & $\bigcirc$ \\
\hline 18 & 電話で扮話ができる & $6 才$ & & & & O & \\
\hline 19 & $\begin{array}{l}\text { 知らない人に道を聞かれた場合、はっきり受け签えがで } \\
\text { る }\end{array}$ & 8 才 & & & & & 0 \\
\hline 20 & 敬語が適当につかえる & 6 才 & & & & & O \\
\hline
\end{tabular}

(4) 集団への参加 (Socialization)

\begin{tabular}{|c|c|c|c|c|c|c|c|}
\hline No. & 項 & \begin{tabular}{|l|} 
Polio $の$ \\
可能年令
\end{tabular} & 同年令 & 1 年差: & 2 年差 & 3 年差 & $\begin{array}{l}4 \text { 年差 } \\
\text { 以 }\end{array}$ \\
\hline 1 & $\begin{array}{l}\text { 友だちといっしょにごっこ遊びができる（乘物ごっこ、マ } \\
\text { マゴト、打店ごっこなど） }\end{array}$ & 6 才 & 0 & & & \multirow{5}{*}{ O } & \\
\hline 2 & ひとりでいるよりみんなといっしょにいることを楽しむ & 6 才 & $\bigcirc$ & & & & \\
\hline 3 & 運動会の練習に喜んで参加する & 6 才 & $\bigcirc$ & & & & \\
\hline 4 & かくれんぼや石けりなどの雄びに加わることができる & 6 才 & & & & & \\
\hline 5 & かくれんぼやブランコなどの遊びの規則や順番が守れる & 6 才 & O & & & & \\
\hline 6 & おもちゃをゆずりあって使 5 & $6 才$ & $\bigcirc$ & & & & \\
\hline 7 & 自分のbのを友だちといっしょに使扰らとする & $6 才$ & 0 & & & & \\
\hline 8 & だれでも喜んで仲間に入れる & $6 才$ & $\bigcirc$ & & & & \\
\hline 9 & 遊び方について、友だちの話を静かに聞く & $6 才$ & $\bigcirc$ & & & & \\
\hline 10 & 学校 (幼稚園) や家庭で行なわれる行事に進んで参加する & & & & & & \\
\hline
\end{tabular}




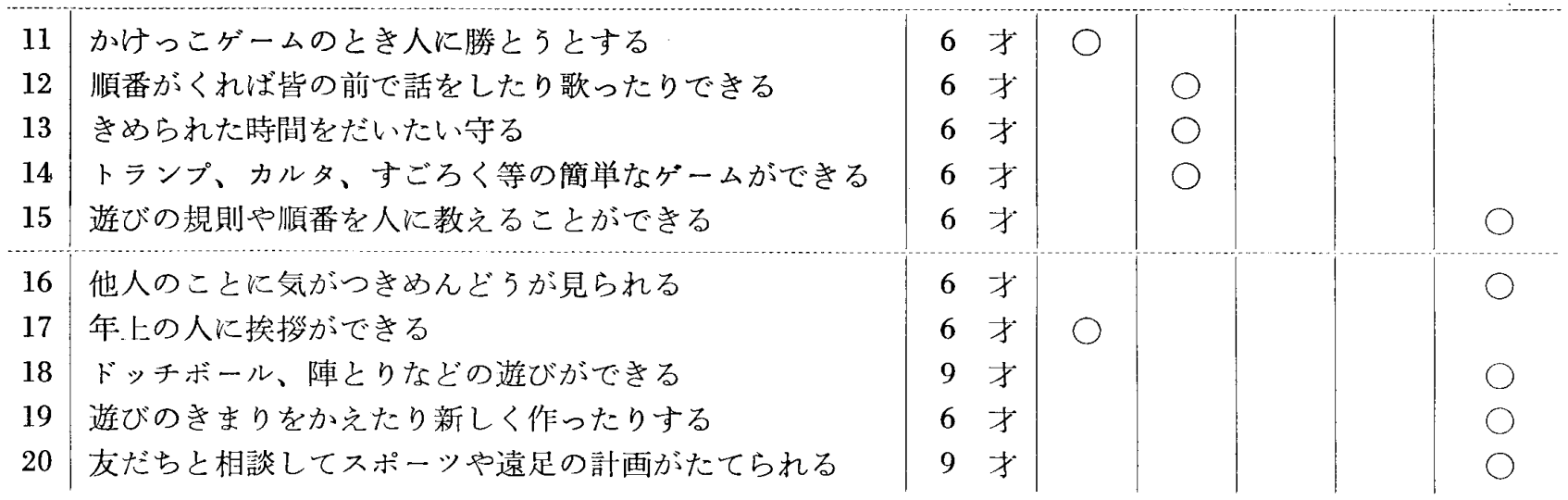

（5）自発性（自主性） (Spontaneity)

\begin{tabular}{|c|c|c|c|c|c|c|c|}
\hline No. & 項 & \begin{tabular}{|l|} 
Polio \\
可能年令
\end{tabular} & 同年令 & 1 年差 & 2 年差 & 3 年差 & $\begin{array}{l}\text { 4年差 } \\
\text { 以 }\end{array}$ \\
\hline 1 & 扣もちやや絵本を自分で出して遊ぶ & 6 才 & 0 & & & & \\
\hline 2 & 自分のものと人のものを区別して扱觉る & $6 才$ & 0 & & & & \\
\hline 3 & けがをしたらすぐ捛となの手当をうけにくる & 6 才 & 0 & & & & \\
\hline 4 & できるだけ戸外で遊ぶ & 6 才 & & & & & $\bigcirc$ \\
\hline 5 & 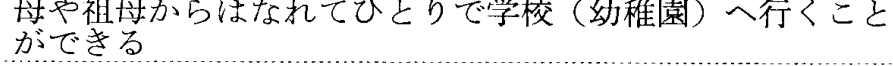 & 6 才 & & & & & 0 \\
\hline 6 & 自分から進んで遊びをはじめる & 6 才 & $\bigcirc$ & & & & \\
\hline 7 & こわれた拈もちゃをな打すように申し出る & 6 才 & 0 & & & & \\
\hline 8 & 友だちの扣もちゃを横取りしない & 6 才 & 0 & & & & \\
\hline 9 & 外に遊びにいくときは、家庭に告げていく & 6 才 & & & & & 0 \\
\hline 10 & 疲れると休息を自分でしょうとする & 6 才 & $\bigcirc$ & & & & \\
\hline 11 & 約束したことをだいたい守る & 6 才 & $\bigcirc$ & & & & \\
\hline 12 & 炎天に出るときすすんで帽子などかぶる & 8 才 & & & 0 & & \\
\hline 13 & 他人の悪い行為を批判できる & 6 才 & $\bigcirc$ & & & & \\
\hline 14 & 絵本をみてしま5ともとにきちんとしま5 & 6 才 & & $\bigcirc$ & & & \\
\hline 15 & 絵本はすぐに説明を求めないで自分で考えながらみる & 6 才 & & & & & O \\
\hline 16 & けがや病気にならないように注意する & 6 才 & & & & & 0 \\
\hline 17 & 病人の看護や忙しいときの手伝いができる & 7 才 & & & & & 0 \\
\hline 18 & おもちゃで遊んだあとは進んでかたつける & 6 才 & & & & & $\bigcirc$ \\
\hline 19 & 遊びやしごとでリーダーになれる & 6 才 & & & & & 0 \\
\hline 20 & いわれないでも怙客さまに挨拶ができる & 6 才 & & & & & $\bigcirc$ \\
\hline
\end{tabular}

（6）自己統制（Self-Control）

\begin{tabular}{|c|c|c|c|c|c|c|}
\hline No. & 項 & $\begin{array}{l}\text { Polio } \\
\text { 可能年令 }\end{array}$ & 同年令 & 1 年差 & 2 年差 3 年差 & $\begin{array}{l}\text { 4 年差 } \\
\text { 以 } 1 .\end{array}$ \\
\hline 1 & 友だちに自分のおすちゃをかすことができる & 6 才 & O & & & \\
\hline 2 & 伦険な場所に近よらない & 6 才 & $\bigcirc$ & & & \\
\hline 3 & 危険な遊びはしない & 6 才 & $\bigcirc$ & & & \\
\hline 4 & 学校 (幼稚園) や抺使いの帰りに道草をくわない & 6 才 & & 0 & & \\
\hline 5 & 病気のとき、扣となしく寝ていることができる & 6 才 & $\bigcirc$ & & & \\
\hline
\end{tabular}




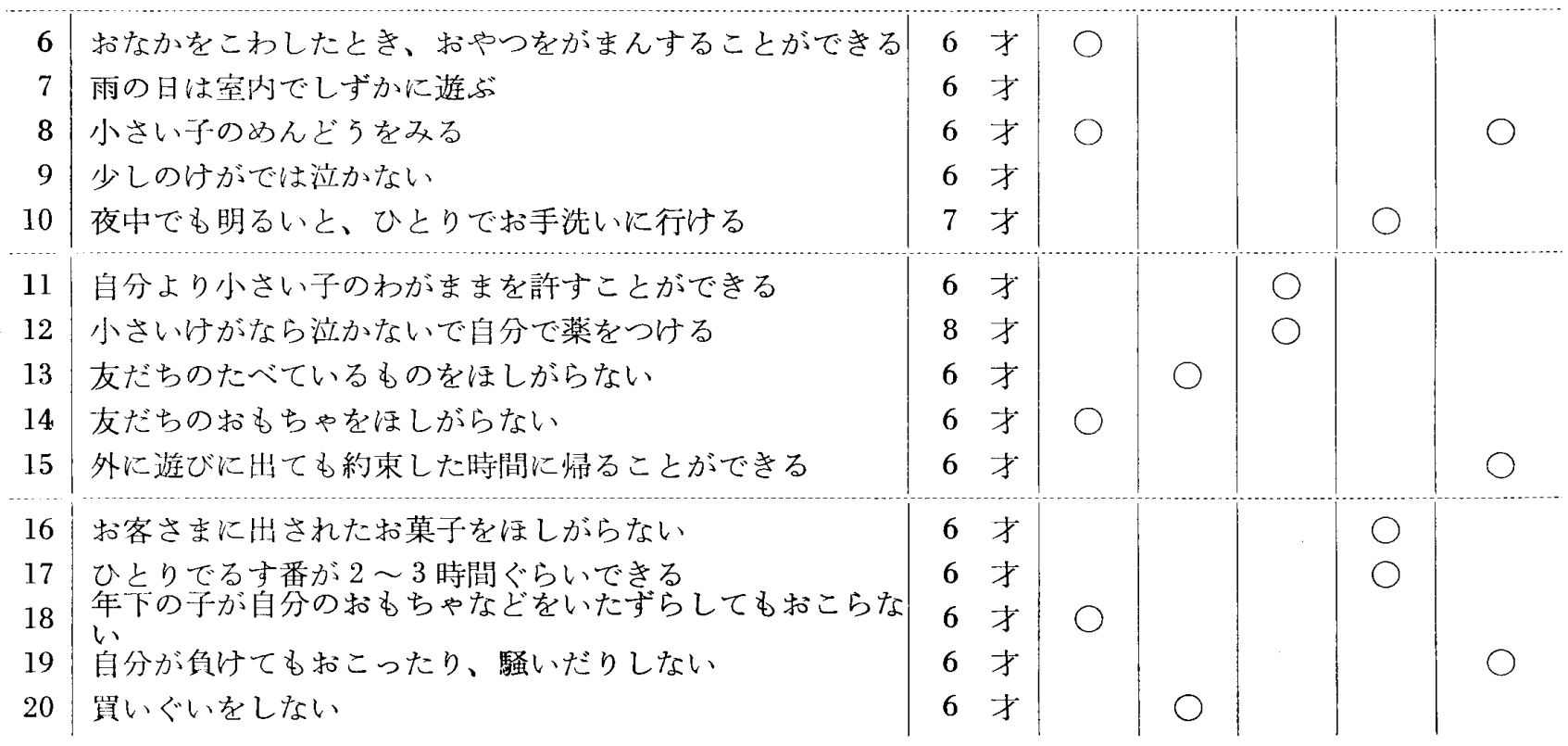

（7a）基本的習慣一清潔--

\begin{tabular}{|c|c|c|c|c|c|c|c|}
\hline No. & 項 & \begin{tabular}{|l|} 
Polio \\
可能年令
\end{tabular} & 同年令 & 1 年差 & 2 年差 & 3 年差 & $\begin{array}{l}4 \text { 年差 } \\
\text { 以上 }\end{array}$ \\
\hline 1 & ひとりで乎を洗うことができる & 6 才 & 0 & & & & \\
\hline 2 & 毛分で鼻をかむことができる & $6 才$ & 0 & & & & \\
\hline 3 & ひとりで㐘ブラシを使って窲をみがくことができる & $6 才$ & $\bigcirc$ & & & & \\
\hline 4 & 入浴は喜んでする & $6 才$ & 0 & & & & \\
\hline 5 & 汗がでたらハンカチでふく & 6 才 & $\bigcirc$ & & & & \\
\hline 6 & 田分で髪をとかすことができる & 6 才 & & $\bigcirc$ & & & \\
\hline 7 & しごとや遊びのあとは手、足、顔を洗 5 & 6 才 & & $\bigcirc$ & & & \\
\hline 8 & はながでたらすぐにかも & 6 才 & $\bigcirc$ & & & & \\
\hline 9 & 蛛呙で身体の主な部分を自分で洗うことができる & 6 才 & & & & & O \\
\hline 10 & 自分で爪をきることができる（きき手を使って） & $6 \gamma$ & & & & & 0 \\
\hline
\end{tabular}

（7b）基本的留慣一排洲一

\begin{tabular}{|c|c|c|c|c|c|c|}
\hline No. & 項 & \begin{tabular}{|l|} 
Polio \\
可能年令
\end{tabular} & 同年令 & 1 年差: 2 年差 & 3 年差 & $\begin{array}{l}\text { 4年差 } \\
\text { 以上 }\end{array}$ \\
\hline 1 & オシメを使わなくてすむ & 9 才 & $\bigcirc$ & & \multirow{4}{*}{$\bigcirc$} & \\
\hline 2 & 祘しっこは完全にひとりでできる & 6 才 & \multirow{4}{*}{$\begin{array}{l}\bigcirc \\
0\end{array}$} & & & \\
\hline 3 & 遊びに夢中になっても、もらすことがない & 6 才 & & & & \\
\hline 4 & おねしょはほとんどしない & 6 才 & & & & \\
\hline 5 & ひとりでさっさと便所へいく & 6 才 & & & $\bigcirc$ & \\
\hline 6 & パンツをよごさない & 6 才 & $\bigcirc$ & & \multirow{5}{*}{$\bigcirc$} & \multirow{5}{*}{$\bigcirc$} \\
\hline 7 & 用便後は、ひとりでよく手を洗う & 6 才 & $\bigcirc$ & & & \\
\hline 8 & 大便は完全にひとりでできる & 6 才 & & & & \\
\hline 9 & 大便のあとうまくふくことができる & 6 才 & & & & \\
\hline 10 & たいてい朝きまった時間に大便をする & 13 才以上 & & & & \\
\hline
\end{tabular}


（7c）基本的習慣一着衣一

\begin{tabular}{|c|c|c|c|c|c|c|c|}
\hline No. & 項 & \begin{tabular}{|l|} 
Polio \\
可能年令
\end{tabular} & 同年令 & 1 年差 & 2 年差 & 3 年差 & $\begin{array}{l}4 \text { 年差 } \\
\text { 以 上 }\end{array}$ \\
\hline 1 & ひとりでたびや靴下をぬぐ & 6 才 & 0 & & & & \\
\hline 2 & ひとりで下駄や靴をはく & 6 才 & & & & $\bigcirc$ & \\
\hline 3 & ひとりでパンッやブルマースなどをはく & $6 才$ & 0 & & & & \\
\hline 4 & ひとりで洋服をぬぐ & $6 才$ & & $\bigcirc$ & & & \\
\hline 5 & ひとりでたびや靴下をはく & $6 才$ & & $\bigcirc$ & & & \\
\hline 6 & 衣服のほころびを親にしらせる & $6 才$ & O & & & & \\
\hline 7 & 洋服のぼたんをかける & $7 才$ & & & & 0 & \\
\hline 8 & 自分で洋服をきる & 7 才 & & & & $\bigcirc$ & \\
\hline 9 & ぬいだ靴をきめられた場所にきちんとおく & $6 才$ & & & & $\bigcirc$ & \\
\hline 10 & ぬいだ着物をせいとんする & 6 才 & & & & O & \\
\hline
\end{tabular}

（7d） 基本的習慣一睡眠一

\begin{tabular}{|c|c|c|c|c|c|c|c|}
\hline No. & 目 & $\begin{array}{l}\text { Polio } 9 \\
\text { 可能年令 }\end{array}$ & 同年令 & 1 年差 & 2 年差 & 3 年差 & $\begin{array}{l}4 \text { 年差 } \\
\text { 以 }\end{array}$ \\
\hline 1 & ねまきに着がえてからねる & 6 才 & $\bigcirc$ & & & & \\
\hline 2 & いつも的ごこへ行ってねる & $6 才$ & $\bigcirc$ & & & & \\
\hline 3 & ねる前に便所へ行く & $6 才$ & 0 & & & & \\
\hline 4 & きまった時間にだいたいねる & $6 才$ & $\bigcirc$ & & & & \\
\hline 5 & ひとりできげんよく起きる & $6 才$ & O & & & & \\
\hline 6 & ひとりできげんよくねる & 6 才 & 0 & & & \multirow{5}{*}{$\bigcirc$} & \\
\hline 7 & へやを暗くしてねる & $6 才$ & O & & & & \\
\hline 8 & 朝早くめをさます & $6 才$ & & & & & \\
\hline 9 & 「扣やすみなさい」と挨拶をしてねる & $6 才$ & $\bigcirc$ & & & & \\
\hline 10 & 自分でねどこの始末をする & $10 才$ & & & & & $\bigcirc$ \\
\hline
\end{tabular}

（7e）基本的習慣一食事一

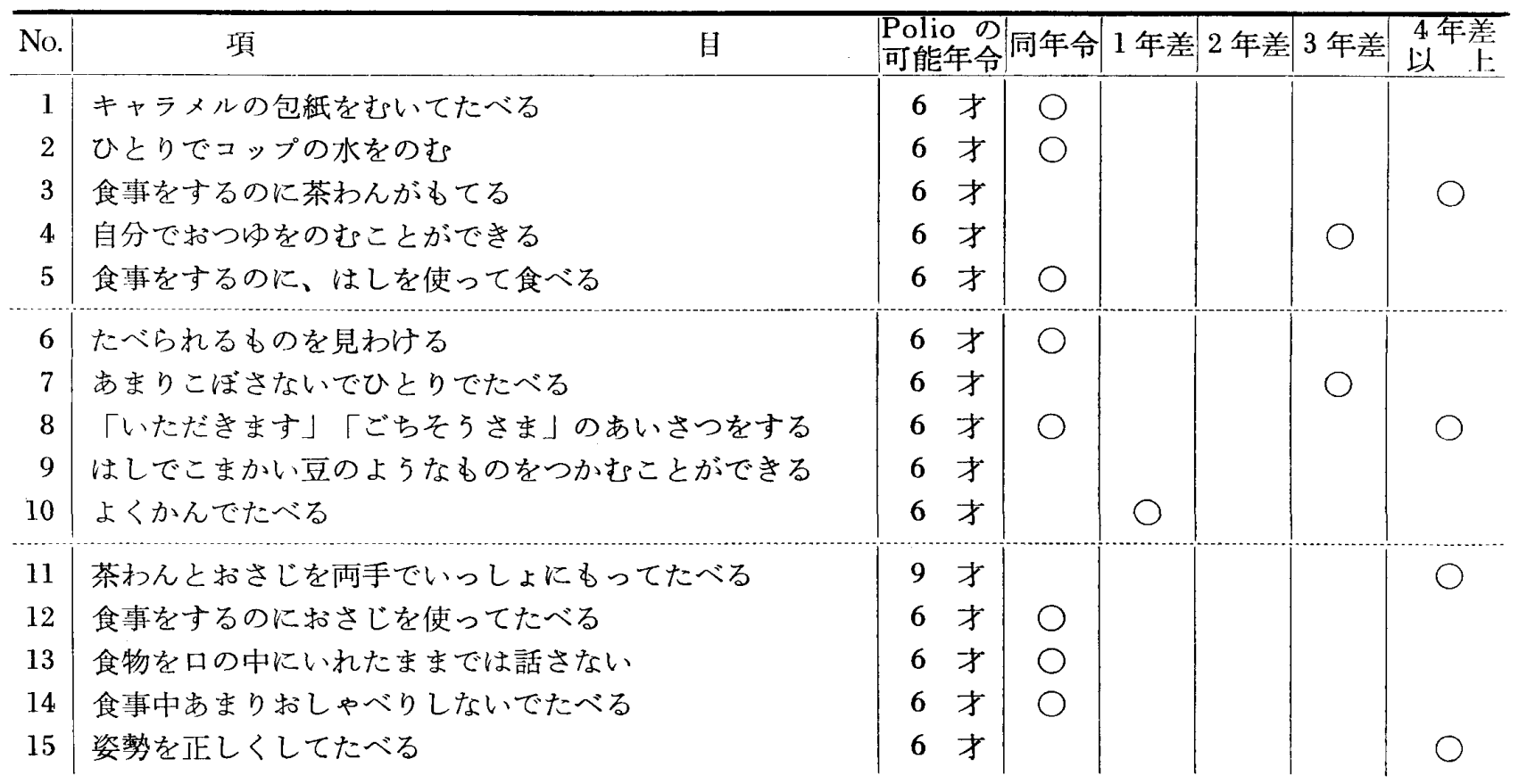




\begin{tabular}{l|l}
16 & ごはんはいつもきれいにたべ終わる \\
17 & 食事のとき手卮いができる \\
18 & 魚の骨などをはしでよりわけてたべる \\
19 & 食事のあとはしばらく静かにしている \\
20 & おやつはきめられた時間にたべる
\end{tabular}

これらのことから、本研究の社会的成熟度において、 Polio 児はC P巟よりもかなり発達していることがわか る。その発達の程度、分野は、前述の上5であるが、今 後の学留指導や生徒指導に参考となろう。

3. 肢体不自由児の個人羑

同じ肢体不自由児といっても、その起因疾患の種類や 障害の程度は、種々様々である。そのため社会的成熟度 に括いても個人差が著しいのではないかと推察される。 そこで、社会的成熟度の総得点の分散（S.D）につい て検討した。Fig. 14 に Polio 児とC P 児の年令別結果

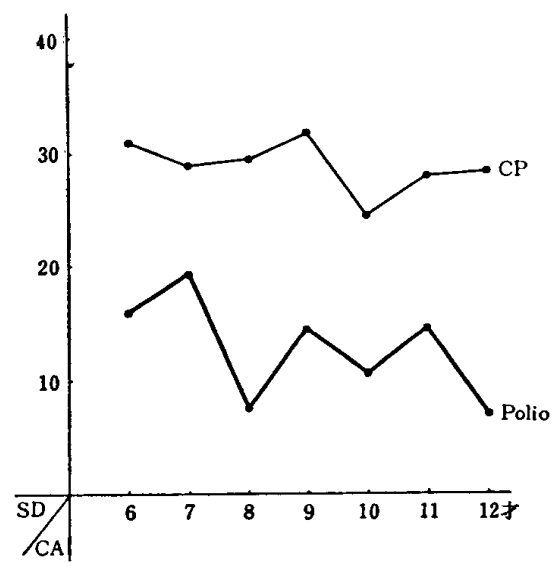

Fig. 14 社会的成熟度の分散の比較

を示した。C P 児と Polio 児とを比較すると、C P 児の 得点の分散は大きく、個人差が著しい。

C P 児は、養護学校在学中のものでも、まひの部位や 程度によって軽度のものから、かなり重症のものまであ り、さらに随伴障害のあるものが多い。それに反して、 Polio 児の場合は、下肢のまひでは、跛行の程度から起 立歩行不能程度のもの、上肢のまひでは、肩関節の運動 障害やひご、手指の障害などで、C P 児に比較すれば軽 度のものが多い。そのため、個人差もC P 児ほど大きく はない。な挍、Polio 児の個人差は、普通児のそれと大 差ない。

つぎに、C P 児と Polio 児の典型的な 2 事例ずつにつ いて、さらに個人差を比較してみよう。

C P児の事例

[事例 1] A.U.男、C. A. 6 : 11、小 1 （神戸市）。

$\mid \begin{array}{ll}6 & \text { 才 } \\ 6 & \text { 才 } \\ 6 & \text { 才 } \\ 8 & \text { 才 } \\ 6 & \text { 才 }\end{array}$

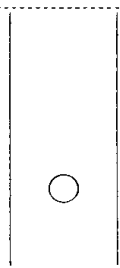

0

0

0

$\bigcirc$

早産で出生時体重 $2250 \mathrm{~g}$ の未熟児。母39才会社員、母 1 人、子 1 人の家庭。知能程度中、国語・算数の学力ともに 中。病型は失調・アテトーゼの両方を㐫わせもつ混合型、 障害個所は、アテトーゼの影響によって、全身にわたっ ている。その程度は上肢については書写速度が遅く、字 もされいでない。下肢は一応歩行可能ではあるが失調が あって、転倒しやすい。言語は軽い構音障害があるが、 他の随伴疾患はない。S A $3: 1 、 S$ Q は45で、社会的 成熟度の各領域とも低い（Fig. 15)。

[事例 2] M.K. 男、C.A. 6：1、小 1 (名古屋市)。

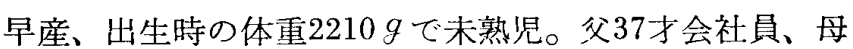
36 才、兄 1 人の 4 人家族。知能程度は中、国語、算数の

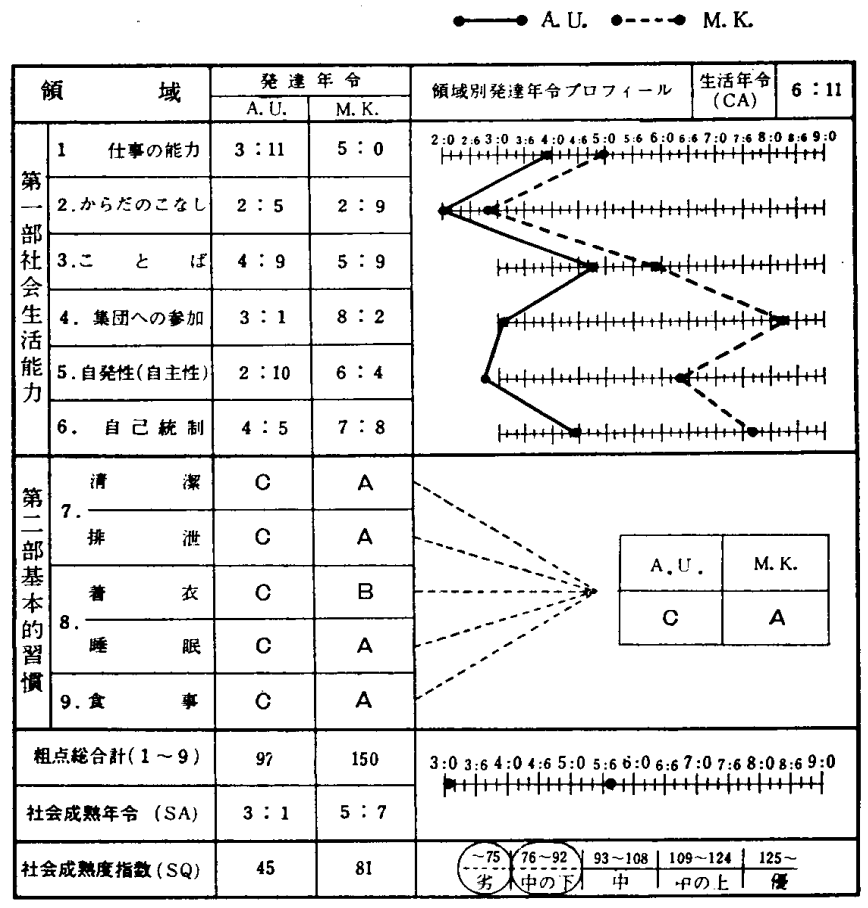

Fig. 15 C P 児の社会的成熟度新断プロフィール

学力とも中。病型は、痤直型といわれ、障害部位につっ ぱりがみられ、上肢の指、両下肢の足、脚にそりがある。 しかし、障害程度は軽度で上肢切ては、日常生活に

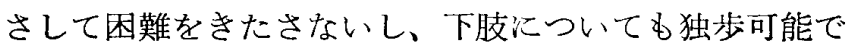
ある。言語は正常である。S A 5：7、S Qは81で社 会的成熟度は、C P 児としては高い方で「中の下」の段 階である (Fig. 15)。 
以上、C P児の 2 事例を比較してみると、起因疾患、年 令、学年、知能、学力、性別、地域などが同じであって も、Fig.15のプロフィールに示したように、社会的成熟 度は、两者にかなりの差異がある。特に、集団への参加、 自発性、自己統制、基本的習慣などの差異が大さい。こ れは障害の程度の違いもあるが、家族構成や家庭での養 育態度の違いなども影響していると考えられる。

Polio 児の事例

[事例 3] Y.K.女、C.A.6：5、小 1 (東京)。 出産時は正常で体重 $3150 \mathrm{~g}$ 、田中ビネーI Q 115、父は 40 才小売商、母 37 才、祖母 65 才、兄 1 人、姉 1 人の 6 人 家族。身体的特徵は、両下肢まひで、矯正靴をはき、松葉 杖にて歩行する Polio 児である。ほかに何ら異常はない が、不満があると口をきかない傾向がある。S A 4：1、 $\mathrm{S} Q$ は64で、社会的成熟度は低い（Fig. 16)。

[事例 4] Y.Y.女、C.A.6：6、小 1 (東京)。 出生時正常で体重 $3810 \mathrm{~g}$ 、田中ビネー I Q 119、父は39 才で会社員、母37才、兄 $7 才 の 4$ 人家族。性格は人にな つき明かるい。時には奇抜なことをして人を笑わせる。両 下肢まひで、矯正鞉、松葉杖步行で他に障害はない。障 害部位、程度とも Y.K. 呪と全く同じである(Fig. 16)。

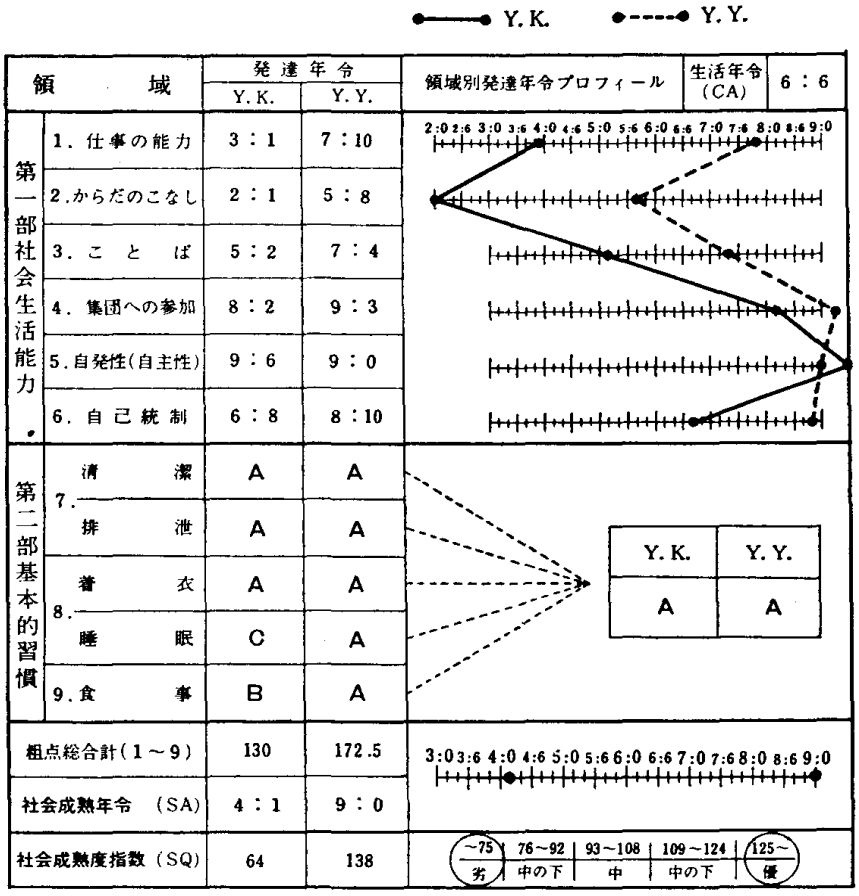

Fig. 16 Polio 児の社会的成熟度診断プロフィール

以上、Polio 児の 2 事例を比較すると、起因疾患、年 令、学年、知能、学力、性別、地域などが同じであっても Fig.16 のプロフィールに示したように、社会的成熟度 には、すでにFig. 14に拈いてみたごとくPolio 児の個 人美は大きくなかったにもかかわらず、なおこのような
差異が示される。な搞本事例に扣いては全体のプロフィ ールの型は類似しているが、仕事の能力、からだのこな し、ことば、睡眠の習慣などの差が大きい。

4. 今後の問題

一般に、肢体不自由児の心理学的評価は、反応の仕方や 表現上の困難点から正確に测定できない面がある 3)4。 特に年少児にはこの傾向が強い。したがって、直接肢体 不自由児を対象に調查しないで、その子を熟知している 保護者とか先生による間接的な評価によって、その子の 諸能力を診断評価する方法が試みられている5 が、その 評価は一般にさずかしい。

1）本研究も質問紙法を用いて、間接的に調査したの であるが、調查の手続き上結果の解釈に限界がある。こ こで得られた社会生活能力は、母親または保護者の目を 通して得た子どもの能力である。そこで、母親または保 護者の目を通すといら主観性はどうしても除かれない。 観察者の社会的条件、教育的関心度、要求水準などによ り同じ子どもの行動のうけとりかたも違ってくるであろ 弓。特に、C P 览の母親は、普通児の母親に比較して、 過保護であり、夫婦の葛藤があったりして問題むある 2) (2) 9)。それらの親の評洒の信頼性にも問題もあろう。

2）本調査は、普通児を対象にした間題内容であって、 普通児にとって日常生活でほとんど問題にならないよう なこと、たとえばいすにすわったり、立ったりすることな どが肢体不自由児には問題であろうが、本問題には含ま れていなかった。また、年令範囲も普通児の 8 才程度ま での問題が多かったのに、本対象では 6〜13才までのも のに実施した。この点今後の課題として、Doll, E. A. らも試みているような肢体不自由坚の問題項目 ${ }^{5}$ をさら に高年令まで適用でさるよ5なるのを作慗し、追跡研究 する必要があろ5。

3）子どもの社会的成熟度は、親の養育態度とも関係 が深い12)。この点、肢体不自由児の親の盖育態度と子 ぞもの社会的生活能力の発達についての関連を研究する 必要があろ5。

4）本研究結果で判明した諸問題を、これからの肢体 不自由児教育のあらゆる面に応用し、Curriculum の作 製、学級編成、校外指導、生活指導などの面での活用が 望なれる。

\section{要 約}

本研究は、肢体不自由児の社会的成熟度について、つ ぎの 3 つの目的で行なった。

1） C P児の中でむ障害部位別に社会的生活能力の発 
達を比較検討すること。

2） C P 児と Polio 児の社会的生活能力の発達の違い を研究すること。

3）肢体不自由児の社会的生活能力八個人美について 比較研究すること。

研究方法は、社会的成熟度に関する.180項目からなる 質問紙法を用いて調查した。これらの項目は、作業能力、 運動 (移動) 能力、意志交換能力、集団への参加能力、 自発性、自己統制、基本的習慣（清潔・排泄・着衣・睡眠 - 食事) の 7 領域に分かれている。質問紙は、全国の10 肢体不用由児盖護学校に在学中の C P览 588 人と Polio 児98人の母親または保護者に配布して記入された。年令 は6〜13才までである。

なお、C P巟は、障害部位別に、 $\mathrm{P}$ (两下肢まひ)、 $\mathrm{Q}$ (両上肢両下肢まひ)、 $\mathrm{H}$ (体の片側まひ)、 $\mathrm{T}$ (片侧 の上肢と下肢まひ）の4群に分類した。これらの研究結 果は、つぎのように概括できる。

1）CP览の中でも障害程度によって、比較的重い $Q$ 群と比較的軽い $\mathrm{P}$ 群とを比較すると、社会的生活能力の 中であ、日常の生活動作に直接影響を与えるような諸動 作たとえば作業能力、清潔、着衣、食事などの諸能力に 差異が現われている。しかし、ことばや知的意志的な諸 能力たとえば意志交換能力、集団への参加能力、自 発 性、白己統制などの諸能力には、これらの傾向はあまり みられなかった。

2）C P 坚と Polio 胃の社会的成熟度を比較すると、 ごく一部の年令を除いて、社会生活能打・基本的習慣の いずれに拈いてもC P児は、Polio 児化比較して、どの 年令に括いても劣っていた。これは、Polio螀は、ビ一 ルスによって脊咕が侵されているが、知的には正常児上 変わらず、まひの程度もC.P児汪ど重くないため、生活 経験も移動能力むC P 児より高いためと考えられる。友 面、C P 児は、脳の運動中权部等の障嗐によるため、運 動発達、知的発達などがひどく遅れているために、社会 性の発達も遅いと考えられる。

な技、C P贤の平均 S Q は57であり、Polio 巟の平均 $\mathrm{S} Q$ は 101 であった。肢体不自由児全体の平均 S Q は64 であった。

3）肢体不自由児の個人养については、その種類や起 因疾患などが種々雑多であって、その程度もまちまちで ある。そのため普通児に比較して社会的成熟度の個人差 は著しく大きい。な拉、C P 児とPolio児とを比較する と、C P 児の個人差の方が大きい。

\section{文献}

1）荒川勇, 古厩勝彦（1963）万5児の社会成熟度.
東京教育大学教育学部紀要, 9, 119 129.

2) Boles, G. (1959) Personality foctors in mothers of corebral palsied children. Genet. Psychol. Monogr, 59, 159 218 .

3) Doll, E. A. (1951) Mental evaluation of children with expressive handicaps. Amer. J. Orthopsychiat., 21(1).

4) Doll, D. A. (1954) Intelligence and cerebral palsy. Cerebral Palsy Review, 15(2), 6〜7.

5) Doll, E. A.:1966 An attainment scale for appraising young children with expressive handicaps. The Cerebral Palsy Journal, 27(5), $3 \sim 5$.

6）橋本重治（1963）肢体不白由罗の心理と教育. 金 子書房, 5 12 .

7) 橋本重治 前述 $46 \sim 51$.

8）橋本重治，松原達或（1967）脳性高ひ少の社会的 成熟度に関する研究. 東京教育大学教育学部紀要, 13, $169 \sim 185$.

9）林邦雄（1966）肢体不白由児の親の熊度. 教育心 理ジャーナル, 日本文化科学社.

10）伊藤徹, 堂本一, 久保和男（1960）養護学校新 入児童に持けるレディネス. 大阪府立養護学校研究紀 要, $3 \sim 39$.

11）松原達战（1964）社会的成熟度の発達と形成要

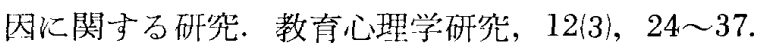

12）松原達战, 小林芳郎 (1964) 親の養育態度と子ど もの社会性に関与る版究(1)(2). 31回日本応用心理学会. 13）三木安让他（1956） 社会牛活能力（精神薄弱児 実態調查委員会絓 精神薄弱巟の安態) 東京大学出版 会, $70 \sim 116$.

14) New Jersey Study (1954) Evaluation and education of the cerebral palsied child. International for Exceptional Children, 37 51 .

15) Phelps, W. M. et al (1958) The Cerebral Palsied Child.（11本浩他訳（1966）脳性マ比. 文光 堂, $162 \sim 169$ )

16）住藤泰伥（1959）盲児, 弱視児の社会性の発達 について. 東京教育大学教育学部紀要， 5, 102 126. 17）鈴木清（1961）社会成熟度骖断検查. 日本文化 科学社.

18）高瀬安貞(緇)（1959）肢体不自由者更生指導の 理論と実際. 肢体不自由者更生援謢会, 69.

19）牛鼠義友（1949）社会的生活能力検查（牛島, 波多野絀，监童の心性と能力検查）政松堂書店，91125. 


\title{
A STUDY ON THE SOCIAL MATURITY OF CRIPPLED CHILDREN
}

\author{
JUJI HASHIMOTO, TATSUYA MATSUBARA AND KUNIO HAYASHI \\ Tokyo University of Education
}

The purposes of this study is ( I ) to compare the development of social competences among four types (Paraplegia, Quadriplegia, Hemiplegia and Triplegia) of cerebral palsied children, (II) to find developmental differences in social competence between ce. rebral palsied children and children with poliomy. elitis, and (III) to investigate individual difference in social competences among the above-mentioned crippled children.

Method: The Questionaire which contained 180 items on social maturity was used. The items were grouped into the following seven aspects on "Occupation", "Locomotion", "Communication", "Socialization", "Spontaneity", "Self-control" and "Fundamental habits" (cleanliness, toilet habits, dressing, sleeping, and feeding oneself). The questionaire was filled out by 588 mothers or guardians with cerebral palsied children and 98 mothers or guardians of children with poliomyelitis who were attending 10 primary schools for crippled children in representative cities of Japan.

The age of the crippled children was between 6 and 13 years. Cerebral palsied children were divided into four groups of Paraplegia (PG), Quadriplegia (QG), Hemiplegia (HG) and Triplegia (TG).

Results: The result of this study was summarized as follows :

(1) The Comparison of social competence between $P G$ and $Q G$ was made.
QG was greatly inferior to $P G$ in such performances of "Occupation", "Cleanliness", "Dressing" and "Feeding oneself" as affect directly on activity of daily life, but there were little differences between both groups in "Communication", "Socialization", "Spontaneity" and "Self-control".

(2) Referring to social maturity, cerebral palsied children at almost all ages were inferior to children with poliomyelitis both in social competence and in fundamental habits.

In this respect, on one hand it is observed that in case of children with poliomyelitis life experience is wider and locomotion remains higher than cerebral palsied children, on the other hand, it is considered that the social development of cerebral palsied children is retarded because of severe multiple handicaps as the result of brain damage.

The average $S Q$ of cerebral palsied children was 57 and that of children with poliomyelitis was 101 . The mean SQ of the above-mentioned crippled children was 64.

(3) There was distinctly individual difference among crippled children in the development of social maturity as compared with normal children because of various degrees of physical involvement and the like.

Individual differences among cerebral palsied children were greater than those among children with poliomyelitis. 